\title{
Evaluation of Some Soil Physical and Chemical Properties of Two Irrigated Plots at Kware Local Government Area, Sokoto State, Nigeria
} \author{
$\mathrm{MS}^{6}$, Dangaladima $\mathrm{W}^{4}$ and Noma $\mathrm{SS}^{1}$ \\ ${ }^{\mathrm{T}}$ Department of Soil Science and Agric. Engr., Usmanu Danfodiyo Univ., Sokoto, Nigeria \\ ${ }^{2}$ Department of Soil Science, Federal University Dutsinma, Katsina, Nigeria \\ ${ }^{3}$ Department of Geography, Usmanu Danfodiyo University, Sokoto, Nigeria \\ ${ }^{4}$ Department of Agricultural Science, Shehu Shagari College of Education, Sokoto, Nigeria \\ ${ }^{5}$ Bangladesh Sugarcrop Research Institute (BSRI) Substation, Chunarughat, Bangladesh \\ ${ }^{6}$ Agricultural Engineering Research Institute (AEnRI), Agric. Research Center, Giza, Egypt
}

Hayatu $\mathrm{NG}^{1}$, Haruna $\mathrm{FD}^{2}$, Dahiru $\mathrm{S}^{1}$, Abdulwahab MO ${ }^{1}$, Saadu I ${ }^{3}$, Sharu MB ${ }^{4 *}$, Alam MA ${ }^{5}$, Hashem

\section{*Corresponding Author}

Sharu MB

\author{
Article History \\ Received: 21.08 .2020 \\ Accepted: 29.08 .2020 \\ Published: 06.09.2020
}

\begin{abstract}
Adequate information on the effects of irrigation on soil physical and chemical properties is critical as it substantially helps in ensuring environmental sustainability. To achieve this, two farmers plot were investigated at Gidan Arju village based on similarities in farming activities. Two profile pits were dug one for each plot and named IrrP1 and IrrP2 respectively. Soil samples collected from the genetic horizon each pedons. The samples were analysed for their physico-chemical properties. The pedons were sandy loam and sandy clay loam in texture at surface and subsurface horizons respectively. The $\mathrm{BD}$ was moderate for both pedons. The soil $\mathrm{pH}\left(\mathrm{H}_{2} \mathrm{O}\right)$ ranged between 7.9-10 and was rated alkaline to strongly alkaline. Statistically, there was no significant variation between the two pedons. However, the entire samples were marginal in total porosity, OC, AP and low in EC. Total nitrogen, CEC, exchangeable $\mathrm{Na}, \mathrm{K}, \mathrm{Mg}$ and $\mathrm{Ca}$ were rated high. Correlation analysis showed insignificant, but negative relationship of BD with TN $(r=-0.562)$, CEC ( $r$ $=-0.304)$ and PBS $(r=-0.396)$. From the results of our study it is recommended that phosphate fertilizer and manure should be supplemented to enhance nutrient status of the soils. Similarly, good quality irrigation water was also recommended to improve the soil $\mathrm{pH}$.
\end{abstract}

Keywords: Environmental sustainability, irrigation, cultivation, pH, correlation analysis.

\section{INTRODUCTION}

As our global population marches steadily toward projections of 9.5 billion people in 2050 , which means a continuous and increased demand for food, it becomes glaring that natural and human-induced soil degradation, if not mitigated, will undoubtedly increase the potential for negative impacts such as disease and malnutrition [1]. To meet the food demand, there is the dire need to maintain an all year-round crop production as food security is the basis of survival. Yet crop production hinges on adequate supply of moisture and nutrients [2, 3]. It thus becomes critical to consider options that increase food production, maximize land resources and enhance productivity. One of such strategies is irrigation, since it opens more lands in dry lands; arid and semi-arid lands ensuring their productivity [4, 5]. Irrigation refers to the artificial application of water to the soil for the purpose of supplying moisture essential for plant growth [6].

Dowgert [7] noted that at global scale, $20 \%$ of cultivated lands are under irrigated agriculture and this contributes to about $40 \%$ of food supplies thus underscoring the role irrigated agriculture plays in food and fibre production. Irrigation not only aims to obtain highest yield per unit land for a particular season but to maximize net returns on a long-term basis. However, irrigation water is a major constraint for assured crop production [8]. Inappropriate irrigation systems are among the principal causes of human-induced salinization in arid and semiarid regions and cause poor soil physical condition. This results in poor crop establishment as a result of water logging which

Copyright @ 2020: This is an open-access article distributed under the terms of the Creative Commons Attribution license which permits unrestricted use, distribution, and reproduction in any medium for non commercial use (NonCommercial, or CC-BY-NC) provided the original author and source are credited. 
changes the hydrologic balance. Poor soil management can also negatively affect the potential use of an area and may ultimately lead to land degradation and loss of productivity [9]. On the other hand, extra irrigation is one of the strategies for salty soils management as it aids leaching excess of salts. Success in agriculture hinges on the sustainable use of soil resources as soil loses its quality and quantity within a short period of time [10].

Soil health maintenance is therefore of great importance for sustained food productivity, decomposition of wastes, storage of heat, sequestration of carbon, and the exchange of gases [11]. Soil been a natural resource cannot be properly managed without proper understanding of their characteristics, as it is essential for good land evaluation which is a pre-requisite for sound land use planning [12-15]. To properly understand and manage soils in a sustainable manner, we find it imperative to study soils under irrigation to add to the wealth of knowledge on the subject matter as there is paucity of information in that regard. Our study was thus carried out on the soil physical and chemical properties of two irrigated plots at Gidan Arju area of Kware local government area of Sokoto state, Nigeria. We studied two farmers' plots at the village after digging profile pits one at each location. We proceeded in assessing soil quality indicators that play role in influencing the biological, physical and chemical properties of the soil. These properties include physical properties such as bulk density, particle size distribution, and total porosity. While the chemical properties measured are soil $\mathrm{pH}$, soil organic matter (OM) and organic carbon (OC), available phosphorus (AP) electrical conductivity (EC), exchangeable bases viz sodium $(\mathrm{Na})$, potassium $(\mathrm{K})$, calcium $(\mathrm{Ca})$, and magnesium $(\mathrm{Mg})$, cation exchange capacity (CEC) and percentage base saturation.

\section{Materials And Methods \\ Description of the Study Area}

This research was conducted at Gidan Arju village, Kware Local Government area, Sokoto state, and located between latitude $13^{0} 13^{\prime \prime} 0^{\prime \prime}$ to $13^{0} 13^{\prime} 30^{\prime \prime} \mathrm{N}$ and longitude $5^{0} 16^{\prime} 30^{\prime \prime}$ to $5^{0} 17^{\prime \prime} 0^{\prime \prime} \mathrm{E}$. The climate of the area is characterized by Tropical climate with an average rainfall of $565 \mathrm{~mm} /$ year [16]. The minimum temperature is $27{ }^{0} \mathrm{C}$ while the maximum temperature is $40{ }^{\circ} \mathrm{C}$ [16]. The relative humidity during dry season is about $15-20 \%$ and reaches up to $70-75 \%$ during the rainy season. Gidan Arju is blessed vast irrigation lands with mostly clay and silt loam soils. Agriculture is one of the dominant activities engaged by the people of the village. The dominant underlying geology of the study area is Cretaceous and Tertiary sediments [17].The vegetation is largely that of the Sudan zone, which contains savannah woodland on the better soils and tree and shrub savannah on the poorer ones. The major land use types in the study were arable crop production both at upland and lowland areas and non-agricultural uses such as residential, quarry and mining, roads construction etc. The major crops cultivated in the area include onions, pepper, tomatoes, etc.

\section{Field Work}

Two (2) farmers plots at the village were purposely selected for the study. The farm lands have been under intensive cultivation for several years. The choice of the two locations was based on similarity in their farming activities and also to enable comparison. Two profile pits $(2 \times 1.5 \times 2 \mathrm{~m})$ one at each location were dug. The general site description such as climate, vegetation, land use, slope gradient, drainage type and condition, type and degree of erosion and depth to ground water table were observed and recorded during the study. The profile pits were also described morphologically following FAO [18] guidelines. For each profile, depth, colour, texture, structure, consistence, roots, pores, inclusions, as well as boundary characteristics were recorded. Garmin eTrex 10 gps device was used to record the location of each farms as well as the profile pit.

\section{Sample Collection and Preparation}

Soil samples were collected from each genetic horizon of the two profile pits dug. Similarly, undisturbed soil samples for bulk density determination were taken using core samplers of known volume, whereas disturbed samples for other physical and chemical parameters determination were taken in nylons, labelled accordingly and transported to the laboratory. The samples for bulk density determination were oven dried at $105^{\circ} \mathrm{C}$ for 48 hours. Disturbed soil samples on the hand, were air-dried for 24 hours, crushed gently using pestle and mortar and pass through 2 mm sieve. Particles $<2$ $\mathrm{mm}$ were used in the laboratory analyses.

\section{Laboratory Analyses}

Soil samples were analyzed for the following parameters: Particle size analysis was determined by the Bouyoucos Hydrometer [19] method. Bulk density was by core sampler method as described by Blake and Hartge [20]. Particle density was determined by the use of Pycnometer bottle method [21]. Total porosity was calculated from particle and bulk density values using the following relationship:

$P=100\left(1-\frac{B d}{P d}\right)$

Where, $\mathrm{P}=$ porosity, $\mathrm{Bd}=$ bulk density, $\mathrm{Pd}=$ particle density of mineral soil $\left(2.65 \mathrm{~g} \mathrm{~cm}^{-3}\right)$ 
Soil $\mathrm{pH}$ was determined both in water and $0.01 \mathrm{M} \mathrm{CaCl}_{2}$ with a glass electrode $\mathrm{pH}$ meter at 1:2.5 soil to liquid ratio [22]. Organic carbon was determined by wet oxidation method as described by Nelson and Sommers [23]. Total nitrogen $(\mathrm{N})$ was determined using the Micro-Kjeldahl digestion and distillation method [24]. Available phosphorus was extracted following Bray No. 1 method and determined using molybdenum blue method [25]. Cation exchange capacity (CEC) was determined by the neutral ammonium acetate saturation method buffered at $\mathrm{pH} 7$ [19]. Exchangeable bases $\left[\mathrm{Ca}, \mathrm{Mg}, \mathrm{K}\right.$ and $\mathrm{Na}$ ] were determined by extraction with neutral $1 \mathrm{~N} \mathrm{NH}_{4} \mathrm{OAC}$ saturation method. $\mathrm{Ca}$ and $\mathrm{Mg}$ were read using atomic absorption spectrophotometer (AAS), whereas $\mathrm{K}$ and $\mathrm{Na}$ were read using Flame Photometer [19]. Percentage base saturation (PBS) of the soils was calculated using the following relationship:

PBS $=\frac{\sum \text { (Exchangeable Bases) }}{\text { CEC }} \times 100$,

Where; $\mathrm{PBS}=$ percent base saturation, $\mathrm{CEC}=$ cation exchange capacity

\section{Data Analysis}

The data generated were analyzed statistically using both descriptive statistics (such as means, ranges, percentages and inferential statistics [such as Pearson's Correlation Analysis (r)].

\section{RESULTS AND DISCUSSION}

\section{Soil Physical Properties as Influenced by Irrigation}

The horizons of both Pedons Irr P1 and P2 were generally sandy loam and sandy clay loam in texture in the surface and subsurface respectively, except for horizon Btk (Irr-P2), which was clay loam in texture (Table 1). In the surface horizons of Pedons Irr P1 and P2, the sand content ranged from 48.4 to $62.2 \%$ (55.3\%). For the underlying horizons, the sand content varied from 44.5 to $64.1 \%(54.3 \%)$. The sand distribution did not vary with depth, particularly in Pedon Irr-P1 and was rated very high. The silt and clay content of the surface horizons of Pedons Irr P1 and P2 ranged from 17.7 to $19.6 \%(18.7 \%)$ and 18.2 to $33.9 \%$ (26.1\%) respectively, whereas in the subsurface horizons, the silt and clay content varied from 7.9 to $15.7 \%(11.8 \%)$ and 22.2 to $39.8 \%(31.0 \%)$ respectively. The silt content of the soils was rated to be generally low, and varied with depth especially in Pedon Irr-P1.

The dominance of sand fractions in the soils may be attributed to nature of the parent materials from which the soils were formed and their weathering; mineral composition of the soils; and/or the composition of the materials deposited into the soils annually via alluvial or colluvial means. This result signifies that the soils are young. According to Sombroek and Zonneveld [17] soils that are formed on the younger surfaces are usually sandy in nature. The variation in clay content in the surface and subsurface horizons of Pedon Irr P1 and P2 was wide and ranged from 18.2 to $39.8 \%$ (29.0\%). The clay content was observed increasing with depth in both Pedons IrrP1 and P2 signifying illuviation process was active in the soils, hence the formation of argillic horizon. Similar result was observed by Lawal [2], which he attributed similar findings to deposition of the materials at different time (chronosequence). Table 2 shows that the soils of Pedons IrrP1 and P2 were generally sandy clay loam in texture. This implies that they can moderately infiltrate water, store large amount of water for plant use and will therefore require less frequent irrigation.

The bulk density values in the surface horizons of the soils ranged between low $\left(1.0 \mathrm{~g} \mathrm{~cm}^{-3}\right)$ to high $\left(1.6 \mathrm{~g} \mathrm{~cm}^{-3}\right)$, whereas that of the subsurface horizons varied between low $\left(1.2 \mathrm{gcm}^{-3}\right)$ to moderate $\left(1.5 \mathrm{~g} \mathrm{~cm}^{-3}\right)$ (Table 1$)$. The low bulk density observed in the both surface and subsurface horizons of Pedons Irr P1 and P2 could be attributed to the organic residue applied by the farmers during field preparation, which tends to reduce their compaction. According to Jones [26] the critical values of bulk density for plant growth at which root penetration is likely to be severely restricted ranges between 1.6-1.8 $\mathrm{g} \mathrm{cm}^{-3}$ for sandy clay loam soils. This shows that, the soils have bulk density less than the critical value, as such are good for effective root penetration. Ap- horizon of Pedon Irr-P1 had a bulk density equal to the critical value $\left(1.6 \mathrm{~g} \mathrm{~cm}^{-3}\right)$, but might not hinder root penetration. Correlation analysis showed insignificant, but negative relationship of bulk density with total nitrogen $(\mathrm{r}=-0.562, \mathrm{P} \leq 0.05), \mathrm{CEC}(\mathrm{r}=-0.304, \mathrm{P} \leq 0.05)$ and $\mathrm{PBS}(\mathrm{r}=-0.396, \mathrm{P} \leq 0.05)$. Similarly, insignificant, but positive relationship between bulk density $(\mathrm{r}=-0.811, \mathrm{P} \leq 0.05)$ and organic carbon was observed (Table $3 \mathrm{~d})$.

The total porosity of the surface horizons of Pedons Irr P1 and P2 ranged from 32 to 55\% (44\%). For the subsurface horizons, the total porosity varied from 40 to $51 \%$ (46\%) (Table 1). The total porosity decreases with increase in soil depth. The low total porosity value observed in the soils may be attributed to long-term effect of tillage resulting in compaction of the soils. The result agrees with the findings of Brady and Weil [27], who opined that, long-term cultivation tends to lower total porosity due to decrease in soil organic matter and increase in large peds. Yakubu et al. [28] attributed similar result to the effect of continuous cultivation, which might have compacted the soil and reduce the pore spaces. Ap-horizon of Irr-P1 recorded the lowest value of total porosity (32\%) which could be attributed to the 
effect of high bulk density $\left(1.6 \mathrm{gcm}^{-3}\right)$ (Table 1) observed. Correlation analysis showed that total porosity negatively, but significantly correlated with bulk density $(r=-0.975, \mathrm{P}<0.01)$ (Table 3$)$.

\section{Soil Chemical Properties as Influenced by Irrigation}

Results of the chemical properties of the soils of irrigated land pedons Irr P1 and P2, are shown in Table 2. The $\mathrm{pH}$ values $\left(\mathrm{pH}_{\mathrm{water}}\right)$ for the irrigated pedons were generally high, values for the surface horizons ranged from 8.0 to 10.0 (9.0) and was rated strongly alkaline. The highest $\mathrm{pH}$ value (10.0) was obtained in pedon Irr-P1. For the underlying horizons the $\mathrm{pH}$ values varied 7.90 to 7.99 (7.95) and was rated strongly alkaline too. The $\mathrm{pH}$ values were nearly similar for all the underlying horizons of the irrigated pedons. The $\mathrm{pH}$ values observed could be attributed to the geology and nature of parent materials from which the soils were formed. Correlation analysis indicated an insignificant, but negative relationship of $\mathrm{pH}(\mathrm{r}=-0.540, \mathrm{P}>0.05)$ with available phosphorus (Table $3 \mathrm{~d})$.

The electrical conductivity values (Table 2) for the surface horizons of pedons Irr P1 and P2 ranged from 0.2 to $0.2 \mathrm{dSm}^{-1}\left(0.2 \mathrm{dSm}^{-1}\right)$ and was rated low. In the subsurface horizons, EC values varied from 0.1 to $0.2 \mathrm{~d} \mathrm{Sm}^{-1}\left(0.15 \mathrm{dSm}^{-}\right.$ ${ }^{1}$ ) and was also rated low. EC values did not vary with depth but differed between pedons Irr P1 and P2. The EC values of pedon Irr-P2 appeared to be higher $\left(0.2 \mathrm{dSm}^{-1}\right)$ than that of pedon Irr-P1 $\left(0.1 \mathrm{dSm}^{-1}\right)$. According to Horneck et al. [29] the critical EC value that affect agricultural crops is $>2.5 \mathrm{dSm}^{-1}$. This shows that the EC values obtained in pedons Irr P1 and P2 are safe for crop growth and development and the soils were neither saline nor sodic. Result of correlation analysis showed significant positive relationship of electrical conductivity $(r=0.082, \mathrm{P}<0.01)$ with bulk density (Table 3).

The organic carbon content of the surface horizons of irrigated land pedons Irr P1 and P2 ranged from 4.99 to $9.98 \mathrm{~g} \mathrm{~kg}^{-1}\left(7.49 \mathrm{~g} \mathrm{~kg}^{-1}\right)$ and was rated low. For the underlying horizons, organic carbon values varied from 4.99 to $8.98 \mathrm{~g}$ $\mathrm{kg}^{-1}\left(6.99 \mathrm{~g} \mathrm{~kg}^{-1}\right)$ and was also rated low (Table 2). The organic carbon content varied irregularly with depth especially in pedon Irr-P1. The low organic carbon status of the soils could be attributed to the cumulative effect of continuous cultivation and conversion of native forest land to irrigated land. Tillage practices are known to soften the soils and consequently facilitate fast organic matter decomposition. Chimdi et al. [30] opined that depletion of soil organic carbon is due to the fact that cultivation increases soil aeration which enhances decomposition of soil organic matter. This result also shows that the soils are susceptible to water erosion. According to Landon [31] low organic carbon content of soils is an indication of their vulnerability to water erosion. Similarly, Barrow [32] observed that an organic carbon content of $<2.0 \mathrm{~g} \mathrm{~kg}^{-1}$ for tropical soils is an indication of soil degradation that may result in high risk of soil erosion. Correlation analysis showed significant, but negative relationship between organic carbon $(\mathrm{r}=-0.332, \mathrm{P}<0.05)$ and percent base saturation (Table 3).

Total nitrogen content of the surface horizons of irrigated land pedons Irr P1 and P2 ranged from 1.86 to $2.03 \mathrm{~g}$ $\mathrm{kg}^{-1}\left(1.95 \mathrm{~g} \mathrm{~kg}^{-1}\right)$ and was rated high (Table 2). For the subsoil horizons, total nitrogen varied from 1.11 to $2.68 \mathrm{~g} \mathrm{~kg}^{-1}$ $\left(1.90 \mathrm{~g} \mathrm{~kg}^{-1}\right)$ and was also rated high. The total nitrogen content values were nearly similar for both Pedons. The total nitrogen values of pedon Irr-P1 varies irregularly with increasing soil depth, while that of pedon Irr-P2 increased with depth. This trend of decreasing TN value (Irr-P2) with depth has agreed with the findings by Dessalegn et al. [33] who observed decrease in TN with depth. The high TN values obtained is contrary to the findings of Noma [34] who observed low to medium values of TN while working on the soils of Sokoto-Rima Floodplains, which covered some parts of Kware local government. The lower TN value observed in the Ap-horizon of Irr-P1 could be attributed to the effect of cultivation that could have also aggravated loss of nitrogen, which corroborate with the findings by Abera and Belachew [35]. Malo et al. [36] also attributed lower nitrogen values to the imbalance between nitrogen added during fertilizer application and nitrogen lost due to harvest removal, leaching and humus losses via cultivation.

Table-1: Physical Properties of the Soils of Gidan Arju Series Pedons Irr P1 and P2

\begin{tabular}{|c|c|c|c|c|c|c|c|c|}
\hline \multirow[t]{2}{*}{ Horizon } & \multirow{2}{*}{$\begin{array}{l}\text { Depth } \\
\text { (cm) }\end{array}$} & \multicolumn{3}{|c|}{ Particle Size Distribution (\%) } & \multirow[t]{2}{*}{ Textural Class } & \multirow{2}{*}{$\begin{array}{l}\text { Bulk } \\
\text { Density } \\
\text { gcm }^{-3}\end{array}$} & \multirow[t]{2}{*}{ Particle Density } & \multirow{2}{*}{$\begin{array}{l}\text { Porosity } \\
(\%)\end{array}$} \\
\hline & & Sand & Silt & Clay & & & & \\
\hline \multicolumn{9}{|c|}{ Gidan Arju Series- Pedon Irr- P1 (Entic Dystruderts/Eutric Vertisols (Loamic) } \\
\hline Ap & $0-29$ & 62.2 & 19.6 & 18.2 & SL & 1.6 & 2.3 & 32 \\
\hline $\mathrm{Bt}$ & $29-54$ & 64.1 & 13.7 & 22.2 & SCL & 1.2 & 2.4 & 51 \\
\hline Btk1 & $54-122$ & 64.1 & 9.8 & 26.1 & SCL & 1.2 & 2.4 & 48 \\
\hline Btk2 & $122-200$ & 64.1 & 7.9 & 28.0 & SCL & 1.5 & 2.5 & 40 \\
\hline \multicolumn{9}{|c|}{ Gidan Arju Series-Pedon Irr- P2 (Typic Dystruderts/Eutric Vertisols (Loamic) } \\
\hline Ap & $0-55$ & 48.4 & 17.7 & 33.9 & SCL & 1.0 & 2.2 & 55 \\
\hline Btk & $55-200$ & 44.5 & 15.7 & 39.8 & $\mathrm{CL}$ & 1.4 & 2.3 & 40 \\
\hline \multicolumn{2}{|l|}{ Mean } & 57.9 & 14.1 & 28.0 & SCL & 1.3 & 2.3 & 44 \\
\hline \multicolumn{2}{|l|}{ SE } & 2.71 & 1.39 & 2.21 & - & 0.08 & 0.04 & 3.12 \\
\hline
\end{tabular}

$\mathrm{SE}=$ standard error 
$\mathrm{SL}=$ sandy loam, $\mathrm{SCL}=$ sandy clay loam, $\mathrm{CL}=$ clay loam

Table-2: Chemical Properties of the Soils of Gidan Arju Series Pedons Irr P1 and P2

\begin{tabular}{|c|c|c|c|c|c|c|c|c|c|c|c|c|c|}
\hline \multirow{2}{*}{ Horizon } & \multirow{2}{*}{ Depth $(\mathrm{cm})$} & \multicolumn{2}{|c|}{ pH $(1: 2.5)$} & \multirow{2}{*}{$\mathrm{EC}\left(\mathrm{dSm}^{-1}\right)$} & \multirow{2}{*}{$\begin{array}{l}\mathrm{OC} \\
\mathrm{gkg}^{-1} \\
\end{array}$} & \multirow[t]{2}{*}{ TN } & \multirow{2}{*}{$\begin{array}{l}\text { AP } \\
\text { mgkg }^{-1}\end{array}$} & \multirow{2}{*}{\multicolumn{2}{|c|}{\begin{tabular}{l|l} 
Ca \\
cmolkg $^{-1}$ \\
\end{tabular}}} & \multirow[t]{2}{*}{$\mathbf{K}$} & \multirow[t]{2}{*}{$\mathrm{Na}$} & \multirow[t]{2}{*}{ CEC } & \multirow{2}{*}{$\begin{array}{l}\text { BS } \\
(\%)\end{array}$} \\
\hline & & Water & $\mathrm{CaCl}_{2}$ & & & & & & & & & & \\
\hline \multicolumn{14}{|c|}{ Gidan Arju Series- Pedon Irr- P1 (Entic Dystruderts/Eutric Vertisols (Loamic) } \\
\hline Ap & $0-29$ & 10.0 & 7.31 & 0.2 & 9.98 & 1.86 & 3.02 & 35.90 & 1.05 & 0.41 & 0.90 & 38.30 & 99.89 \\
\hline $\mathrm{Bt}$ & 20.54 & 7.98 & 7.38 & 0.1 & 5.99 & 2.68 & 6.03 & 34.30 & 1.34 & 0.17 & 0.89 & 36.80 & 99.73 \\
\hline Btk & & 90 & 7.41 & & 4.99 & 2.39 & 6. & 30.10 & 0.35 & 0.26 & 4 & 0 & 99.84 \\
\hline Btk2 & $122-200$ & 7.95 & 7.48 & 0.1 & 8.98 & 1.22 & 6.79 & 37.60 & 0.45 & 0.17 & 0.80 & 39.30 & 99.29 \\
\hline \multicolumn{14}{|c|}{ Gidan Arju Series- Pedon Irr- P2 (Typic Dystruderts/Eutric Vertisols (Loamic) } \\
\hline Ap & $0-55$ & 7.99 & 7.46 & 0.2 & 4.99 & 2.03 & 3.39 & 54.40 & 0.48 & 0.48 & 1.07 & 56.50 & 99.88 \\
\hline Btk & $55-2$ & 7.99 & 7.37 & 0.2 & 5.00 & 1.11 & 3.39 & 51.50 & 0.53 & 0.29 & 1.11 & 53.60 & 99.68 \\
\hline \multicolumn{2}{|l|}{ Mean } & 8.25 & - & 0.2 & 6.66 & 1.88 & 4.84 & 40.63 & 0.70 & 0.30 & 0.97 & 42.72 & 99.72 \\
\hline \multicolumn{2}{|l|}{ SE } & 0.19 & & 0.02 & 0.95 & 0.32 & 3.17 & 2.08 & 0.13 & 0.03 & 0.15 & 2.16 & 0.94 \\
\hline
\end{tabular}

$\mathrm{SE}=$ standard error, $\mathrm{pH}=$ soil reaction, $\mathrm{EC}=$ electrical conductivity, $\mathrm{OC}=$ organic carbon, $\mathrm{TN}=$ total nitrogen, $\mathrm{AP}=$ available phosphorus, $\mathrm{CaCl}_{2}=$ calcium chloride, $\mathrm{Ca}=$ calcium, $\mathrm{Mg}=$ magnesium, $\mathrm{K}=$ potassium, $\mathrm{Na}=$ sodium, $\mathrm{CEC}=$ cation exchange capacity, $\mathrm{Mg}=$ magnesium, $\mathrm{BS}=$ base saturation.

Table 3: Correlation (r) Analysis of the Soils of Gidan Arju Series Pedons Irr P1 and P2

\begin{tabular}{|c|c|c|c|c|c|c|c|c|c|c|c|c|c|c|c|}
\hline & Sand & Silt & Clay & BD & Por & pH & OC & TN & $\mathbf{A P}$ & $\mathbf{C a}$ & Mg & $\mathbf{K}$ & $\mathrm{Na}$ & CEC & PBS \\
\hline Silt & -0.489 & & & & & & & & & & & & & & \\
\hline Clay & $-0.863 *$ & -0.018 & & & & & & & & & & & & & \\
\hline BD & 0.280 & -0.007 & -0.316 & & & & & & & & & & & & \\
\hline Por & -0.155 & -0.145 & 0.261 & $\begin{array}{l}- \\
0.975 * *\end{array}$ & & & & & & & & & & & \\
\hline $\mathrm{pH}$ & 0.202 & 0.627 & -0.595 & 0.617 & -0.706 & & & & & & & & & & \\
\hline OC & 0.518 & 0.052 & -0.624 & $0.811^{*}$ & -0.757 & 0.721 & & & & & & & & & \\
\hline $\mathrm{TN}$ & 0.457 & 0.055 & -0.556 & -0.562 & 0.574 & -0.029 & $\overline{0}-279$ & & & & & & & & \\
\hline $\mathrm{AP}$ & 0.697 & $\begin{array}{l}-932 * * \\
0.93\end{array}$ & -0.259 & -0.073 & 0.250 & -0.540 & $\overline{0}-\overline{0}$ & 0.257 & & & & & & & \\
\hline $\mathrm{Ca}$ & $\begin{array}{l}- \\
0.944 * *\end{array}$ & 0.479 & 0.805 & -0.307 & 0.215 & -0.197 & $\overline{0}-\overline{377}$ & $\begin{array}{l}- \\
0.473\end{array}$ & -0.661 & & & & & & \\
\hline $\mathrm{Mg}$ & 0.342 & 0.405 & -0.626 & $0.169 * *$ & -0.110 & 0.448 & 0.310 & 0.473 & -0.100 & -0.311 & & & & & \\
\hline $\mathrm{K}$ & -0.522 & 0.790 & $0.141 *$ & -0.218 & 0.029 & 0.453 & $\overline{0}-\overline{0}$ & $-\overline{0}$ & -0.833 & $0.557 * *$ & -0.143 & & & & \\
\hline $\mathrm{Na}$ & -0.773 & 0.355 & 0.680 & -0.513 & 0.343 & -0.267 & $\overline{0}-\overline{794}$ & $-\overline{0}$ & $\overline{0}-504 * *$ & 0.581 & -0.425 & 0.499 & & & \\
\hline CEC & $-0.944 *$ & 0.502 & 0.791 & -0.304 & $0.212 * *$ & -0.180 & $\begin{array}{l}- \\
0.372\end{array}$ & $\begin{array}{l}-\bar{l} \\
0.460\end{array}$ & -0.676 & 0.999 & $\begin{array}{l}-280 * * \\
0.28\end{array}$ & 0.563 & 0.577 & & \\
\hline PBS & $-0.208^{*}$ & 0.701 & -0.167 & -0.396 & 0.244 & $0.373^{*}$ & $\overline{0}-332$ & 0.573 & -0.569 & 0.084 & 0.229 & $0.683^{*}$ & 0.573 & 0.100 & \\
\hline EC & -0.756 & 0.869 & 0.363 & $0.082 * *$ & -0.258 & 0.476 & 0.001 & $\begin{array}{l}- \\
0.377\end{array}$ & 0.987 & 0.734 & -0.037 & 0.838 & 0.523 & 0.744 & $0.477 * *$ \\
\hline
\end{tabular}

$\mathrm{BD}=$ bulk density, $\mathrm{Por}=$ porosity, $\mathrm{OC}=$ organic carbon, $\mathrm{TN}=$ total nitrogen, $\mathrm{AP}=$ available phosphorus, $\mathrm{Ca}=\mathrm{calcium}, \mathrm{Mg}=\mathrm{magnesium}$, $\mathrm{K}=$ potassium, $\mathrm{Na}=$ sodium, $\mathrm{CEC}=$ cation exchange capacity, $\mathrm{PBS}=$ percent base saturation, $\mathrm{EC}=$ electrical conductivity .

The value of available phosphorus in the surface horizons of pedons IrrP1 and P2 ranged from 3.02 to $3.39 \mathrm{mg}$ $\mathrm{kg}^{-1}\left(3.21 \mathrm{mg} \mathrm{kg}^{-1}\right)$ and was rated low. For the subsurface horizons, available phosphorus varied from 3.39 to $6.79 \mathrm{mg} \mathrm{kg}$ ${ }^{1}$ (5.09 $\mathrm{mg} \mathrm{kg}^{-1}$ ) and was also rated low (Table 2). The available phosphorus content did not vary with depth between both pedons, however, it showed an increasing trend with depth in pedon Irr P1. This result is contrary to the findings by Sheleme [37], who observed decreased in available phosphorus values down the pedons as a result of concomitant increase in clay content in the lower horizons that fix P. According to Brady and Weil [27] phosphorus fixation tends to be more pronounced and ease of phosphorus release tends to be low in those soils with higher clay content. In this study, insignificant negative correlation between available phosphorus $(\mathrm{r}=-0.259, \mathrm{P}>0.05)$ and clay content was observed (Table 3). Table 1 showed increasing clay content with depth. For instance, Pedon Irr-P1 had the following sequence in terms of clay content $\mathrm{Ap}<\mathrm{Bw}<\mathrm{Bwk} 1<\mathrm{Bwk}$, with the following values 18.2, 22.2, 26.1 and 28.0\% respectively. The relatively lower available $P$ values observed in surface horizons $\left(3.02\right.$ and $\left.3.39 \mathrm{mg} \mathrm{kg}^{-1}\right)$ as compared to subsurface horizons could be attributed also to the depletion of organic matter content in surface horizons due to continuous cultivation and fixation of $\mathrm{P}$ applied to the soils via P-containing fertilizers.

The calcium, magnesium, potassium and sodium contents in the surface horizons of pedons Irr P1 and P2 ranged from 35.90 to $54.40 \mathrm{cmol} \mathrm{kg}^{-1}$ (45.15 $\left.\mathrm{cmol} \mathrm{kg}^{-1}\right), 0.48$ to $1.05 \mathrm{cmol} \mathrm{kg}-1$ ( $\left.0.77 \mathrm{cmol} \mathrm{kg}^{-1}\right), 0.41$ to $0.48 \mathrm{cmol} \mathrm{kg}^{-1}(0.45$ cmol kg$)^{-1}$ ) and 0.90 to $1.07 \mathrm{cmol} \mathrm{kg}^{-1}\left(0.99 \mathrm{cmol} \mathrm{kg}^{-1}\right)$ respectively. For the underlying horizons, $\mathrm{Ca}, \mathrm{Mg}, \mathrm{K}$ and $\mathrm{Na}$ content varied from 30.10 to $51.50 \mathrm{cmol} \mathrm{kg}{ }^{-1}$ (40.80 $\left.\mathrm{cmol} \mathrm{kg}^{-1}\right), 0.35$ to $1.34 \mathrm{cmol} \mathrm{kg}^{-1}\left(0.85 \mathrm{cmol} \mathrm{kg}^{-1}\right), 0.17$ to $0.29 \mathrm{cmol}^{-1}$ $\mathrm{kg}^{-1}\left(0.23 \mathrm{cmol} \mathrm{kg}^{-1}\right)$ and 0.80 to $1.11 \mathrm{cmol} \mathrm{kg}^{-1}\left(0.95 \mathrm{cmol} \mathrm{kg}^{-1}\right)$ respectively. The dominant exchangeable bases in these soils appeared to be $\mathrm{Ca}$ and $\mathrm{Na}$. The $\mathrm{Ca}$ and $\mathrm{Na}$ contents tend to decrease with depth, though not in a predictable manner. 
Magnesium and potassium contents of the soils ranged from medium to high, and also followed similar trend with Ca and $\mathrm{Na}$ (Table 2). The amount and distribution of the exchangeable cations appeared to have been influenced by the type of parent material as reported by Ufot et al. [38] and Noma [34]. This trend of decreasing content of exchangeable bases with increasing depth from surface to subsurface horizons is contrary to the findings by Heluf and Wakene [39] and Dessalegn et al. [33]. According to Dessalegn et al. [33] the content of exchangeable cations increased with increasing soil depth, which could be attributed to their leaching from surface horizon down to subsurface. The result of the present findings could therefore, be attributed to the erosion hazard, the soils were exposed to.

In the surface horizons of pedons Irr P1 and P2, the cation exchange capacity varied from 38.30 to $56.50 \mathrm{cmol}$ $\mathrm{kg}^{-1}\left(47.4 \mathrm{cmol} \mathrm{kg}^{-1}\right)$ and was rated high. For the underlying horizons, CEC values ranged from 31.80 to $53.60 \mathrm{cmol} \mathrm{kg}^{-1}$ (42.7 $\mathrm{cmol} \mathrm{kg}^{-1}$ ) and were rated high (Table 2). The CEC content varied with depth of the pedons. The values were generally higher in the surface horizons of both Irr-P1 and Irr-P2, and were observed decreasing with depth, which is contrary to the previous findings $[34,33]$ who reported higher CEC values in the subsurface and observed CEC values increasing with depth. Only Btk2-horizon $\left(39.30 \mathrm{cmol} \mathrm{kg}^{-1}\right)$ of Irr-P1 did not follow this trend, it has CEC value higher than that of the surface Ap-horizon $\left(38.30 \mathrm{cmol} \mathrm{kg}^{-1}\right)$. This irregularity could be attributed to the high clay content $(28.0 \%)$ observed in the Btk2-horizon of pedon Irr P1 (Table 2) which was relatively higher than that of horizons above it which agrees with the findings of Lekwa et al. [40]. Correlation analysis (Table 3) indicated an insignificant positive correlation between CEC and clay content of the soils $(\mathrm{r}=0.971, \mathrm{P} \leq 0.05)$. The high clay content observed (Table 1$)$ in the surface horizons may be due to deposition of clay materials as alluvial and/or colluvial deposit; following erosion and mechanical weathering of the nearby Kuru-kuru hill.

In the surface horizons of pedons Irr P1 and P2, the percent base saturation ranged from 99.88 to $99.89 \%$ (99.89\%) and was rated high. For the underlying horizons, percent base saturation varied from 99.29 to $99.84 \%(99.57 \%)$ and was also rated high (Table 2). The percent did not vary with depth and between the Pedons Irr P1 and P2, but appeared to be similar and high. This result showed similarity in the parent materials from which the pedons Irr P1 and P2 were formed. It also indicated that leaching of exchangeable bases was low and that the soils were of high buffering capacity. Pedon Irr-P1 had the highest base saturation of $99.89 \%$ for the top horizon $(0-29 \mathrm{~cm})$ probably due to high content of exchangeable bases.

\section{CONCLUSION}

Based on the findings of this research, it is evident that the soil of the two plots was sandy loam and sandy clay loam which support crop production. The $\mathrm{pH}$ of the soils which was in the alkaline range may need to be managed to the neutral range as this could pose the problem of salinity if proper remediation option is not enforced. The cation exchange capacity (CEC) level is presently high which favours high potential for retaining of plant nutrients however, the total porosity, organic matter (OM), organic carbon (OC) and available P are low which clearly indicates the poor health status of the soils as these parameters contribute immensely to soil biological, chemical and physical properties as well as crop growth. The findings also indicated that there is a dire need for artificial application of phosphate fertilizers and organic manure to build the deficient elements. Proper monitoring of the soil condition in the village is also critical to prevent further degradation thus frequent studies of soils in the location should be carried out to determine the changes and extent of degradation since some soil nutrients change quickly and guides to efficient nutrient management. Additionally, on both plots, quality irrigation water should be provided and proper irrigation scheduling should be ensured. This is because soil moisture is critical in supplying the water needs of a crop and helps in making nutrients available to the plant. Excess water in soils depletes oxygen $\left(\mathrm{O}_{2}\right)$ and builds up carbon dioxide $\left(\mathrm{CO}_{2}\right)$ levels thus impeding root respiration due to high and toxic $\mathrm{CO}_{2}$ levels.

\section{REFERENCES}

1. Sanchez, P.A., \& Swaminathan, M.S. (2005). Cutting world hunger in half. Science, 307, 357-359.

2. Lawal, B. A., Ojanuga, A. G., Tsado, P. A., \& Mohammed, A. (2013). Characterization, classification and agricultural potentials of soils on a toposequence in southern guinea savanna of Nigeria. World Academy of Science, Engineering and Technology International Journal of Agricultural and Biosystems Engineering, 7(5), 330-334.

3. Umeri, C. (2015). Nitrogen and potassium status of selected soils and their effect on the growth, yield and cyanide content of cassava (Manihot esculenta Crentz) in Delta State, Nigeria. Ph.D. Thesis Department of Crop Science, Ambrose, Alli University, Ekpoma, Edo State, Nigeria.

4. Adhan, M.N. (2009). Evaluation of livelihood, soil and water resources in smallholder irrigation schemes along the Tana River in Garissa District. MSc Thesis: University of Nairobi.

5. Ndegwa, G.M., \& Kiiru, I. (2011). Investigations on soil and water quality as affected by irrigation in Turkana district, Kenya. Journal of Agriculture, Science and technology. Jomo Kenyatta University College of Agriculture and Technology. 
6. Adejumobi, M.A., Ojediran, J.O., \& Olabiyi, O.O. (2014). Effects of Irrigation Practices on Some Soil Chemical Properties on OMI Irrigation Scheme. Int. Journal of Engineering Research and Applications, 4(10S-2):29-35.

7. Dowgert, M.F. (2010). The Impact of Irrigated Agriculture on a Stable Food Supply. Netafim Irrigation Inc. Fresno. Proceedings of the 22nd Annual Central Plains Irrigation Conference, Kearney, NE., February 24-25, 2010 Available from CPIA, 760 N. Thompson, Colby, Kansas.

8. Reddy, S.R. (2012). Principles of Crop Production. $4^{\text {th }}$ edition. Kalyani Publishers, 120-398.

9. Khan, T.O. (2014). Soil Degradation, Conservation, and Remediation. Springer Dordrecht Heidelberg New York London, 32-132.

10. Kiflu, A., \& Beyene, S. (2013).Effects of different land use systems on selected soil properties in South Ethiopia. Journal of Soil Science and Environmental Management, 4(5):100-107.

11. Nanganoa, L. T., Okolle, J. N., Missi, V., Tueche, J. R., Levai, L. D., \& Njukeng, J. N. (2019). Impact of different land-use systems on soil physicochemical properties and Macrofauna Abundance in the humid tropics of Cameroon. Applied and Environmental Soil Science, 2019.

12. Iloeji, S.I. (2003). General Geography of Nigeria. Heinemann Books Ibadan.

13. Idoga, S., \& Azagaku, D. E. (2005). Characterization and classification of soils of Janta area, Plateau State of Nigeria. Nigerian Journal of Soil Science, 15, 116-122.

14. Lawal, B.A. (2011). Semi-detailed soil survey and land evaluation in Lower River Oshin floodplains, Kwara state, Nigeria. An Msc. Research Thesis submitted to the Department of Soil Science and Agricultural Engineering, UDU, Sokoto (unpublished).

15. Olueh, C.E. (2014). Evaluation of potassium status in some soils of Delta state, Nigeria. Ph.D. Thesis Department of Soil Science, Ambrose, Alli University, Ekpoma, Edo State, Nigeria.

16. NMA. (2011). Nigerian Meteorological Agency. Sultan Abubakar International Airport Sokoto, Nigeria.

17. Sombroek, W. G., \& Zonneveld, I. S. (1971). Ancient dune fields and fluviatile deposits in the Rima-Sokoto river basin (NW Nigeria): geomorphologic phenomena in relation to Quaternary changes in climate at the southern edge of the Sahara (No. 5). Stichting voor Bodemkartering Wageningen.

18. FAO. (2006). Guidelines for Soil Description. Fourth Edition. Food and Agriculture Organization of the United Nations Rome, Italy, 109.

19. ISRIC/FAO. (2002). Procedures for soil analysis, sixth edition. In: L.P. Van Reeuwijik (ed.), International Soil Reference and Information Center/FAO, 119.

20. Blake, G.R., \& Hartge, K.H. (1986). Bulk density. In: Klute A. (ed.) Methods of Soil Analyses. Part 1. $2^{\text {nd }}$ ed. Agron. 9. ASA and SSA, Madison, W1, 363-375.

21. Black, C.A. (1965). Methods of Soil and Plant Analyses. Agron. No.9, Part 2 Amer. Soc. Madison.

22. Thomas, G. W. (1996). Soil pH and Soil Acidity. In: D. L. Sparks (ed.) Methods of Soil Analysis Part 3 - Chemical Methods. SSSA Book Series 5, Madison, Wisconsin, USA. 475 - 490.

23. Nelson, D. W., \& Sommers, L. E. (1996). Total carbon, organic carbon, and organic matter. Methods of soil analysis: Part 3 Chemical methods, 5, 961-1010.

24. Bremner, J. M. (1996). Nitrogen-total. Methods of Soil Analysis: Part 3 Chemical Methods, 5, 1085-1121.

25. Kuo, S. (1996). Part 3, chemical methods. Methods of soil analysis. Madison, WI: Soil Science Society of America and American Society of Agronomy, 898-899.

26. Jones, M. J., \& Wild, A. (1975). Soils of the West African savanna; the maintenance and improvement of their fertility. Commonwealth Agricultural Bureaux.

27. Brady, N.C., \& R.R. Weil. (2014). The Nature and Properties of Soils. $14^{\text {th }}$ ed. Pearson Education, Singapore. 976.

28. Yakubu, M. T., Akanji, M. A., Oladiji, A. T., \& Adesokan, A. A. (2008). Androgenic potentials of aqueous extract of Massularia acuminata (G. Don) Bullock ex Hoyl. stem in male Wistar rats. Journal of Ethnopharmacology, 118(3), 508-513.

29. Horneck, D. A., Sullivan, D. M., Owen, J. S., \& Hart, J. M. (2011). Soil test interpretation guide.

30. Chimdi, A., Gebrekidan, H., Kibret, K., \& Tadesse, A. (2012). Status of selected physicochemical properties of soils under different land use systems of Western Oromia, Ethiopia. Journal of Biodiversity and Environmental Sciences, 2(3), 57-71.

31. Landon, J.R. (1991). Booker Tropical Soil Manual: A Handbook for Soil Survey and Agricultural Land Evaluation in Tropics and Subtropics. Longman, London.

32. Barrow, C.J. (1991). Land Degradation: Development and Break-down of Terrestrial Environments. Cambridge University Press, Cambridge.

33. Dessalegn, D., Beyene, S., Ram, N., Walley, F., \& Gala, T. S. (2014). Effects of topography and land use on soil characteristics along the toposequence of Ele watershed in southern Ethiopia. Catena, 115, 47-54.

34. Noma, S. S. (2005). Properties, genesis and classification of Sokoto-Rima floodplains at Sokoto, Nigeria (Doctoral dissertation, Ph. D. Thesis, Department of Soil Science and Agricultural Engineering, Usmanu Danfodiyo University, Sokoto.(Unpublished)).

35. Yifru, A., \& Taye, B. (2011). Land use effects on soil organic carbon and nitrogen in some soils of Bale, Southeastern Ethiopia. Tropical and Subtropical Agroecosystems, 14(1), 229-235. 
36. Malo, D. D., Schumacher, T. E., \& Doolittle, J. J. (2005). Long-term cultivation impacts on selected soil properties in the northern Great Plains. Soil and Tillage Research, 81(2), 277-291.

37. Sheleme, B. (2011). Characterization of soils along a toposequence in Gununo area, southern Ethiopia. Journal of Science and Development, 1(1), 31-41.

38. Ufot, U., Okere, J. U., Anene, B. O. A., \& Ugwu, T. O. (2001, November). Properties, classification and site suitability evaluation of some wetland soils of Abakaliki, Nigeria. In Proceedings of the 27th Annual conference of the Spil Science Society of Nigeria, held at the University of Calabar, Nigeria, November (pp. 5-9).

39. Gebrekidan, H., \& Negassa, W. (2006). Inmpact of Land use and management practices on Chemical properties of some soils of Bako area, Western Ethiopia. Ethiopian Journal of Natural Resources.

40. Lekwa, M.U., Akamigbo, F.O.R., \& Lekwa, G. (2001). A detailed soil survey of the soil of Igwu river floodplain, Arochukwu local government area, Abia state, Nigeria, for swamp rice production. In: Ojeniyi, S.O., I.E. Esu, U.C. Amalu, F.O.R. Akamigbo, I.J. Ibanga and B.A. Raji (eds), Management of Wetland Soils for Sustainable Agriculture and Environment. Proceedings of the $27^{\text {th }}$ Annual Conference of the Soil Science Society of Nigeria held at Calabar, $5^{\text {th }}-9^{\text {th }}$ November. $78-89$ pp.

41. Latitude. (2016). latitude.to/map/ng/nigeria/cities/kware\#gmapz. Accessed on Tuesday $2^{\text {nd }}$ August, 2016. 